\title{
NAAG Peptidase Inhibitors Act via mGluR3: Animal Models of Memory, Alzheimer's, and Ethanol Intoxication
}

\author{
Rafal T. Olszewski ${ }^{1} \cdot$ Karolina J. Janczura $^{1} \cdot$ Tomasz Bzdega $^{1} \cdot$ Elise K. Der $^{1}$ • \\ Faustino Venzor ${ }^{1} \cdot$ Brennen O'Rourke $^{1} \cdot$ Timothy J. Hark $^{1} \cdot$ Kirsten E. Craddock $^{1}$ • \\ Shankar Balasubramanian ${ }^{1} \cdot$ Charbel Moussa $^{2} \cdot$ Joseph H. Neale $^{1} \odot$
}

Received: 12 September 2016 / Revised: 8 January 2017 / Accepted: 16 January 2017 / Published online: 11 March 2017

(c) The Author(s) 2017. This article is published with open access at Springerlink.com

\begin{abstract}
Glutamate carboxypeptidase II (GCPII) inactivates the peptide neurotransmitter $N$-acetylaspartylglutamate (NAAG) following synaptic release. Inhibitors of GCPII increase extracellular NAAG levels and are efficacious in animal models of clinical disorders via NAAG activation of a group II metabotropic glutamate receptor. mGluR2 and mGluR3 knock-out (ko) mice were used to test the hypothesis that mGluR3 mediates the activity of GCPII inhibitors ZJ43 and 2-PMPA in animal models of memory and memory loss. Short- (1.5 h) and long- (24 h) term novel object recognition tests were used to assess memory. Treatment with ZJ43 or 2-PMPA prior to acquisition trials increased long-term memory in mGluR2, but not mGluR3, ko mice. Nine month-old triple transgenic Alzheimer's disease model mice exhibited impaired shortterm novel object recognition memory that was rescued by treatment with a NAAG peptidase inhibitor. NAAG peptidase inhibitors and the group II mGluR agonist, LY354740, reversed the short-term memory deficit induced by acute ethanol administration in wild type mice. 2-PMPA also moderated the effect of ethanol on short-term memory in mGluR2 ko mice but failed to do so in mGluR3 ko mice. LY354740 and ZJ43 blocked ethanol-induced motor activation. Both GCPII inhibitors and LY354740 also significantly moderated the loss of motor coordination induced by $2.1 \mathrm{~g} / \mathrm{kg}$ ethanol treatment. These data support the conclusion that inhibitors of glutamate carboxypeptidase II are
\end{abstract}

Joseph H. Neale

nealej@georgetown.edu

1 Department of Biology, Georgetown University, 37th and O Sts., N.W., Washington, D.C. 20057-1225, USA

2 Department of Neuroscience, Georgetown University, Washington, D.C. 20057, USA efficacious in object recognition models of normal memory and memory deficits via an mGluR3 mediated process, actions that could have widespread clinical applications.

Keywords $N$-Acetylaspartylglutamate $\cdot$ NAAG ·

Memory · mGluR3 knockout mice · Alzheimer's mice ·

Ethanol intoxication - Glutamate carboxypeptidase II . GCPII
Abbreviations
NAAG $N$-Acetylaspartylglutamate
mGluR Metabotropic glutamate receptor
mGluR2 Metabotropic glutamate receptor type 2
mGluR3 Metabotropic glutamate receptor type 3
ko
Knockout
GCPII Glutamate carboxypeptidase II

\section{Introduction}

$N$-Acetylaspartylglutamate (NAAG), a prevalent and widely distributed peptide co-transmitter, is inactivated by glutamate carboxypeptidase II (GCPII) following synaptic release [1]. Inhibitors of GCPII [2, 3] are effective in animal models of several clinical conditions [reviewed in 4-6]. These inhibitors enhance long-term memory in the $24 \mathrm{~h}$ delay novel object recognition test [7], improve memory in an animal model of multiple sclerosis [8], rescue behaviors and short-term memory impairment in animal models of schizophrenia [9-11]. Consistent with these results, mice that are null mutant for GCPII demonstrate full memory in the $24 \mathrm{~h}$ delay novel object recognition test, while their heterozygous littermates and wild type C57B1 mice exhibit no significant recall in this test of long-term memory [7]. GCPII inhibitors also are analgesic in models 
of inflammatory and neuropathic pain [12-14] and reduce the effects of traumatic brain injury [15] while GCPII knockout (ko) mice are protected from peripheral neuropathy and ischemic and traumatic brain injury [16-18].

NAAG reduces transmitter release from neurons and synaptosomes via a group II mGluR receptor $[19,20]$. Inhibitors of GCPII elevate extracellular levels of NAAG and also reduce the release of glutamate and other transmitters [13, 21, 22]. These neurochemical actions of the peptidase inhibitors and their positive effects in animal models are blocked by the group II mGluR antagonist LY341495. While a substantial body of data supports the conclusion that the peptide activates a group II metabotropic receptor $[4,20]$, highly purified NAAG fails to activate mGluR2 or mGluR3 receptors expressed in transfected cells [23, 24], results suggesting that some reports of NAAG activation of a group II mGluR were due to the presence of low levels of residual glutamate $(\leq 0.5 \%$ [25]) in commercially available NAAG. In contrast, data from other studies preclude the conclusion that the NAAG activity is due to this level of contaminating glutamate [20]. Consistent with an action of NAAG at mGluR3, NAAG peptidase inhibition blocks the motor activation effects of phencyclidine in mGluR2, but not mGluR3, ko mice [10]. In those studies where the effects of NAAG or NAAG peptidase inhibition have not been shown to be blocked by a group II mGluR antagonist, it is possible that NAAG is acting as an antagonist at a subclass of NMDA receptors [26].

In order to further test the hypothesis that a group II mGluR, specifically mGluR3, mediates the procognitive efficacy of GCPII inhibitors, these compounds were tested across a series of animal models that included short- and long-term novel object memory, Alzheimer's disease, and acute alcohol intoxication, using a group II antagonist in wild type mice and testing mice that are null mutant for mGluR2 and mGluR3.

\section{Methods}

\section{Animals}

The experimental protocols used in this research were approved by the Georgetown University Animal Care and Use Committee and are consistent with guidelines of the US National Institutes of Health. Efforts were made to reduce animal suffering and to minimize the number of animals used. Adult male C57BL/6NCr mice from the National Cancer Institute, Frederick Research Center were tested once at 2-4 months of age and used for all studies except those involving the knock out or transgenic mice. The mGluR2 and mGluR3 ko mice (knock out R1 cell lines into $\mathrm{C} 58 \mathrm{Bl} / 6$ mice and backcrossed into ICR[CD1] mice)
[27] were provided by Eli Lilly Pharmaceuticals and tested twice at 3-5 months of age in a novel object recognition study. Wildtype littermates for these ko mouse colonies were not available. There are no published studies that compare the performances of these ko mice with their wild type littermates in the novel object recognition test. The tripletransgenic mouse model ( $3 \times \mathrm{Tg}$ line) that expresses three genes associated with familial Alzheimer's disease, namely $\mathrm{APP}_{\mathrm{Swe}}, \mathrm{PS} 1_{\mathrm{M} 146 \mathrm{~V}}$, and tau $\mathrm{P}_{\mathrm{P} 01 \mathrm{~L}}$ [28] were from Jackson Labs (Strain: B6;129-Psen1 Tg(APPSwe,tauP301L)1Lfa/ Mmjax; genetic background: $(129 \times 1 / \mathrm{SvJ}$ x $129 \mathrm{~S} 1 / \mathrm{Sv})$ F1-Kitl<+>; JAX MMRRC Stock\# 034830) and tested at 2-9 months of age in the short-term novel object recognition test. Mice were housed 5 to a cage and maintained on a 12:12 h light-dark cycle with food and water available ad libitum. Behavioral testing was performed during the light cycle between 10 am and $4 \mathrm{pm}$.

\section{Drugs}

The GCPII/NAAG peptidase inhibitor ZJ43 (ZJ43 (N-[[[(1S)-1-carboxy-3-methylbutyl]amino]carbonyl]L-glutamic acid) was synthesized as previously described [9] and provided by Alan Kozikowski. The GCPII inhibitor 2- ((2-(phosphonomethyl)pentane-1, 5-dioic acid) [3, 29]) was from Reagents4Research, LLC (Hangzhou, CN). LY341495, a selective group II mGluR antagonist [30], and LY354740, a heterotropic group II mGluR agonist [31], were from Tocris Cookson Ltd. (Bristol, UK). All compounds were dissolved in saline and $\mathrm{pH}$ was adjusted to 7.4 prior to i.p. injection. Ethanol ( $2.1 \mathrm{~g} / \mathrm{l}$, ip) was given as a concentration of $20 \% \mathrm{v} / \mathrm{v}$ in saline. Doses of ZJ43, 2-PMPA, LY341495, LY354740 and ethanol were based on data from published and preliminary studies.

\section{Novel Object Recognition Test}

Novel object recognition is a validated and widely used test for assessing recognition memory [32-35], including in studies of aging $[36,37]$ and Alzheimer's disease mouse models $[38,39]$. Individual mice (3-4 month old) were placed in a $22 \times 32 \times 30 \mathrm{~cm}$ testing chamber with beige walls for a $5 \mathrm{~min}$ habituation interval followed by i.p. injection with saline, 2-PMPA $(50 \mathrm{mg} / \mathrm{kg})$ or ZJ43 $(150 \mathrm{mg} /$ $\mathrm{kg}$ ), with or without LY341495, and returned to home cage. Thirty minutes later, mice were placed in the testing chamber for $10 \mathrm{~min}$ with two identical objects (acquisition session). Mice were returned to home cages and $1.5 \mathrm{~h}$ (short-term memory) or $24 \mathrm{~h}$ (long-term memory) later were returned to testing chamber in the presence of one of the original objects and one novel object (recognition session) for $10 \mathrm{~min}$. Wild type mice exhibit short-term but not long-term memory in this test $[7,10]$. The original objects 
consisted of two smooth surfaced weighted red cylinders $7 \mathrm{~cm}$ high $\times 4 \mathrm{~cm}$ diameter at base. The novel object consisted of a blue, $7 \mathrm{~cm}$ high $\times 5 \mathrm{~cm}$ diameter (base) round pyramid. The acquisition and recognition sessions were video recorded and the time mice spent exploring each object was assessed by an observer who was blinded to drug treatment and genotype. The chambers and objects were cleaned with ethanol between trials. Exploratory behavior was defined as sniffing, touching and directing attention to the object. In preliminary studies, naïve mice exhibited no significant preference for the red cylinder or the blue pyramid. Exploration time (Table 1) is expressed as the mean \pm the standard error of the mean (SEM). For the acquisition session, the recognition index was calculated as (time exploring one of the objects/the time exploring both objects) $\times 100$. For the recognition session, the RI was calculated as (time exploring the novel object/the time exploring both the familiar and novel object $) \times 100$.
To study the effects of ethanol on short-term memory, mice were placed the testing chamber for a $5 \mathrm{~min}$ habituation interval followed by injection with saline, ZJ43 (150 mg/kg), 2-PMPA (100 mg/kg) or LY354740 (2, 5, $10 \mathrm{mg} / \mathrm{kg}$ ) and returned to home cage. Thirty minutes later mice were injected with ethanol $(2.1 \mathrm{~g} / \mathrm{kg}$, i.p. $)$ and returned to their home cage for 10 min after which they were placed in a testing chamber for $10 \mathrm{~min}$ with two identical objects (acquisition session). Mice were returned to home cages and $1.5 \mathrm{~h}$ later were placed back into the testing chamber for $10 \mathrm{~min}$ in the presence of one of the original objects and one novel object (recognition session).

\section{Open Field Motor Activation Test}

High doses of ethanol induces increases in motor activity (40) and loss of coordination (41) in mice. In the present study, mice were habituated to an open field chamber (Med
Table 1 Exploration time data from short-term (Figs. 2, 3, and 4) and long-term novel object recognition (Fig. 1)

\begin{tabular}{|c|c|c|c|c|c|}
\hline \multirow[t]{2}{*}{ Group } & \multirow[t]{2}{*}{$\mathrm{N}$} & \multicolumn{2}{|c|}{ Acquisition session (s) } & \multicolumn{2}{|c|}{ Recognition session (s) } \\
\hline & & FO (1) & FO (2) & NO & FO (2) \\
\hline \multicolumn{6}{|c|}{$\mathrm{m} 2 \mathrm{ko}$ and $\mathrm{m} 3 \mathrm{ko}$ mice-long-term memory-Fig. 1} \\
\hline m2ko-saline & 11 & $13.7(0.8)$ & $13.6(0.9)$ & $8.2(1.2)$ & $8.2(1.1)$ \\
\hline $\mathrm{m} 2 \mathrm{ko}-\mathrm{PMPA}$ & 12 & $15.3(0.9)$ & $15.0(0.9)$ & $16.5(1.1)$ & $6.2(0.9)$ \\
\hline $\mathrm{m} 2 \mathrm{ko}-\mathrm{ZJ} 43$ & 11 & $14.6(1.2)$ & $15.1(1.2)$ & $10.5(1.3)$ & $5.2(0.7)$ \\
\hline m3ko-saline & 11 & $18.3(0.9)$ & $18.7(0.5)$ & $12.3(1.2)$ & $12.0(1.2)$ \\
\hline m3ko-PMPA & 11 & $17.8(1.1)$ & $17.6(0.9)$ & $13.6(2.2)$ & $13.0(2.3)$ \\
\hline m3ko-ZJ43 & 12 & $17.7(0.9)$ & $18.1(0.8)$ & $13.7(1.3)$ & $12.6(1.0)$ \\
\hline \multicolumn{6}{|c|}{ AD mice—Fig. 2—short -term memory—Fig. 2} \\
\hline 8 Weeks saline & 15 & $11.4(1.0)$ & $12.5(1.1)$ & $22(3.5)$ & $12.6(2.7)$ \\
\hline 5 Months saline & 12 & $4.5(0.7)$ & $5.1(0.8)$ & $6.6(0.9)$ & $6.8(0.7)$ \\
\hline 9 Months saline & 10 & $22.3(3.3)$ & $21.3(3.9)$ & $26.6(4.4)$ & $25.9(3.5)$ \\
\hline 9 Months PMPA & 10 & $19.9(2.5)$ & $20.8(3.5)$ & $45.2(5.4)$ & $27.4(6.0)$ \\
\hline \multicolumn{6}{|c|}{ Ethanol treated mice-short-term memory-Figs. 3 and 4} \\
\hline $\mathrm{S}-\mathrm{S}$ & 10 & $20.4(1.9)$ & $21.4(2.5)$ & $25.2(2.0)$ & $11.9(1.6)$ \\
\hline S-EtOH & 11 & $25.2(1.9)$ & $27.0(2.1)$ & $21.8(2.0)$ & $18.5(1.8)$ \\
\hline ZJ43-EtOH & 6 & $14.2(2.0)$ & $16.0(2.4)$ & $10.7(2.6)$ & $5.33(1.2)$ \\
\hline 2-PMPA-EtOH & 6 & $11.5(0.7)$ & $11.0(0.8)$ & $8.3(1.3)$ & $2.8(0.9)$ \\
\hline LY40 (2)-EtOH & 12 & $3.1(0.4)$ & $2.8(0.4)$ & $4(1.0)$ & $4.2(1.4)$ \\
\hline LY40 (5)-EtOH & 12 & $2.9(0.4)$ & $3.2(0.5)$ & $6.6(1.0)$ & $2.6(0.3)$ \\
\hline LY40 (10)-EtOH & 7 & $4.14(1.0)$ & $4.2(1.0)$ & $8.0(2.6)$ & $2.9(0.6)$ \\
\hline mGluR2ko-S & 11 & $45.5(4.9)$ & $45.7(7.4)$ & $60.7(9.4)$ & $31.0(5.5)$ \\
\hline mGluR2ko-EtOH & 12 & $12.7(2.7)$ & $13.3(2.5)$ & $23.6(4.6)$ & $20.2(3.5)$ \\
\hline mGluR2ko-PMPA + EtOH & 10 & $7.0(1.5)$ & $7.3(1.4)$ & $14.5(2.3)$ & $9.7(1.5)$ \\
\hline mGluR3ko-S & 9 & $20.8(2.5)$ & $17.7(3.2)$ & $21.3(3.5)$ & $12.7(2.9)$ \\
\hline mGluR3ko-EtOH & 9 & $8.0(2.4)$ & $7.1(2.6)$ & $14.3(3.3)$ & $15.1(3.0)$ \\
\hline mGluR3ko-PMPA + EtOH & 10 & $5.4(1.0)$ & $6.3(1.4)$ & $12.8(3.4)$ & $12.9(3.6)$ \\
\hline
\end{tabular}

FO time spend exploring familiar object, $N O$ time spent exploring novel object, LY4O LY354740 (group II agonist). Exploration time for each group expressed as the mean \pm the standard error of the mean (SEM). mGluR ko were tested for long-term memory $24 \mathrm{~h}$ after acquisition session (Fig. 1). mGluR ko, control mice and treated mice were tested for short-term memory $1.5 \mathrm{~h}$ after acquisition session (Figs. 2, 3, and4) 
Associates, St., Albans, Vermont, ENV-515 $43 \times 43 \mathrm{~cm}$, with infrared beams and detectors) for $30 \mathrm{~min}$ prior to i.p. injection with saline, ZJ43 (150 mg/kg)with or without LY341495 (3 $\mathrm{mg} / \mathrm{kg}$ ), or with LY354740, returned to the chamber for $15 \mathrm{~min}$, and injected (i.p.) with $2.1 \mathrm{~g} / \mathrm{kg}$ of ethanol. Locomotor activity was then recorded as distance travelled during $10 \mathrm{~min}$ in the open field chamber.

\section{Rotorod Test}

The rotorod was used to assess motor coordination and balance. Mice were injected (i.p.) with saline, ZJ43 (150 g/kg), 2-PMPA $(10,50,100 \mathrm{mg} / \mathrm{kg})$ with or without LY341495, or with LY354740 (10 mg/kg), returned to their home cage in the testing room and 15 min later were injected (i.p.) with $2.1 \mathrm{~g} / \mathrm{kg}$ ethanol. Forty-five minutes later mice were placed on the drum ( $70 \mathrm{~mm}$ dia) facing away from the direction of the rotation so they can walk forward at constant speed (4 rpm) for $10 \mathrm{~s}$ of habituation. The drum was then accelerated over $3 \mathrm{~min}$, from 0 to $40 \mathrm{rpm}$ (with cut off time $=3 \mathrm{~min}$ ) and the latency to fall from the drum was recorded. Each animal was tested three times with $15 \mathrm{~min}$ between trials.

\section{Statistical Analysis}

For the novel object recognition test, the time spent exploring each object was analyzed by two-way repeated measures ANOVA, with session as within-subject factor and treatment as a between-subject factor. Discrimination ratio data were analyzed by one-way ANOVA followed by Student-Newman-Keuls post-hoc test. Motor activation data and rotorod data were analyzed with GLM ANOVA followed by post-hoc Tukey test.

\section{Results}

\section{Total Exploration Times}

The time exploring individual objects during acquisition trials and recognition trials for each treatment group are presented in Table 1. Within treatment groups, there was a wide range of total exploration times in the acquisition and retention sessions. Drug treatments combined with ethanol tended to result in less attention to the objects during the acquisition trials. This was particularly evident in the LY354740 with ethanol $(2.1 \mathrm{~g} / \mathrm{kg})$ treatment groups but also observed in the ko mice treated with ethanol. An additional anomaly is the substantial difference in the total exploration times of mGluR2 ko/saline treated mice versus the mGluR2ko/ethanol treated mice. Despite these differences between groups, there are clear and significant drug effects in the recognition sessions. The reliability of the novel object recognition data is supported by the fact that, despite differences in the total exploration times among the treatment groups, both objects are nearly equally attended during the acquisition session across all groups and that the recognition data fall clearly into two categories: nearly equal attention to both objects (failed memory) or significantly greater attention to the novel object than familiar object (memory). There were no apparent effects of 2-PMPA or ZJ43 on mean exploration times during the acquisition trials relative to saline treated mice.

\section{NAAG Peptidase Inhibitors ZJ43 and 2-PMPA are Procognitive for Long-term Memory in mGluR2 and but not mGluR3 Knockout Mice}

Mice lacking functional mGluR2, like wild type C57BL mice [7], explored the two similar objects to the same extent during the acquisition trial and failed to discriminate the between the novel and familiar objects when tested one day later (Fig. 1). Also as in wild type mice [7], both NAAG peptidase inhibitors, ZJ43 (150 mg/kg, i.p.) and 2-PMPA $(50 \mathrm{mg} / \mathrm{kg}$, i.p.) increased $(\mathrm{p}<0.001)$ exploration of the novel object when the drugs were given prior to the acquisition trial on day 1 .

mGluR3 knockout mice also spent similar amounts of time exploring the two identical objects during the acquisition trial and the novel and familiar object during the retention trial. However, neither ZJ43 nor 2-PMPA was procognitive in these mice based on their failure to elicit greater exploration of the novel object in the retention trial.

\section{NAAG Peptidase Inhibitor 2-PMPA is Procognitive for Short-Term Memory in Triple Transgenic Alzheimer's Mice}

The triple-transgenic (3xTg line) mice express three genes associated with familial Alzheimer's disease, APP Swe $_{\text {, }}$

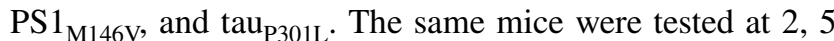
and 9 months of age in the novel object test of short-term memory. At 2 months of age, these mice demonstrated short-term memory while they failed in this test at 5 and 9 months of age (Fig. 2). The 9-month old mice had a high level of exploratory behavior in both the acquisition and retention trials (Table 1). Treatment with $100 \mathrm{mg} / \mathrm{kg}$ of 2-PMPA prior to the acquisition phase reversed this memory deficit $(\mathrm{p}=0.05)$ in the 9 -month old mice as demonstrated by their level of exploration of the novel object relative to the familiar object. 


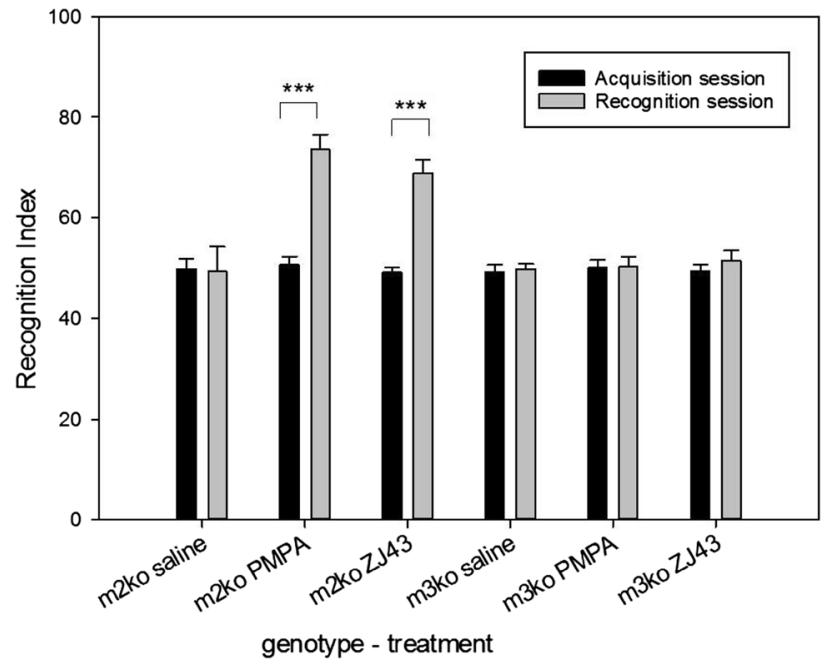

Fig. 1 Long-term novel object recognition memory test in mGluR2 and mGluR3 $\mathrm{KO}$ mice. In this and the following novel object recognition figures: for the acquisition session, the recognition index (RI) was calculated as (time exploring one of the objects/the time exploring both objects) $\times 100$. For the recognition session, the RI was calculated as (time exploring the novel object/the time exploring both the familiar and novel object) $\times 100$. During the acquisition phase, each group of mice explored each of the two identical objects about the same amount of time (recognition index 50). During the recognition phase $24 \mathrm{~h}$ later, the mGluR2 $\mathrm{KO}$ mice (m2ko) treated with saline explored the novel and familiar object similar amounts of time while those treated with 2-PMPA $(100 \mathrm{mg} / \mathrm{kg})$ or ZJ43 $(150 \mathrm{mg} / \mathrm{kg})$ explored the novel object twice as often as the original object (recognition index $\sim 70$ ), while the NAAG peptidase inhibitors had no procognitive effect in the mGluR3 ko mice (m3ko). $\mathrm{m} 2 \mathrm{ko} / \mathrm{saline}$, $\mathrm{n}=11 ; \mathrm{m} 2 \mathrm{ko} / \mathrm{PMPA}, \mathrm{n}=12 ; \mathrm{m} 2 \mathrm{ko} / \mathrm{ZJ} 43, \mathrm{n}=11 ; \mathrm{m} 3 \mathrm{ko} /$ saline, $\mathrm{n}=11$; m3ko/PMPA, $\mathrm{n}=11 ; \mathrm{m} 3 \mathrm{ko} / \mathrm{ZJ} 43, \mathrm{n}=12 . * \mathrm{p}<0.05, * * \mathrm{p}<0.01$, $* * * \mathrm{p}<0.001$ for comparison between acquisition session and recognition session within treatment group in Figs. 1, 2 and 3

\section{Acute Ethanol Intoxication and Short-Term Memory}

C576BL/6 mice (3-4 month old) treated with saline prior to the acquisition trial explored the two identical objects about the same amount of time (Fig. 3) and when presented with one novel object and one familiar object $1.5 \mathrm{~h}$ later, they explore the novel object about twice as frequently as the familiar object [11]. In this study, there was a main effect of treatment and session $\left(\mathrm{F}_{(6,59)}=4.51\right.$, $\left.\mathrm{p}<0.01, \mathrm{~F}_{(1,59)}=199.32, \mathrm{p}<0.001\right)$ and a treatment $\mathrm{x}$ session interaction $\left(\mathrm{F}_{(6,59)}=3.73, \mathrm{p}<0.01\right)$. Mice treated with ethanol $(2.1 \mathrm{~g} / \mathrm{kg}$, i.p. $)$ prior to the acquisition trial also explored the two objects about the same amount of time. However, in contrast to the saline treated control mice, the ethanol treated mice explored the novel and familial objects equally in the retention trial suggesting a failure to recall or recognize the familiar object relative to the novel one. The NAAG peptidase inhibitors ZJ43 $(150 \mathrm{mg} /$ $\mathrm{kg}), 2$-PMPA $(100 \mathrm{mg} / \mathrm{kg})$ and the type $2 / 3$ metabotropic glutamate receptor agonist LY354740 $(10 \mathrm{mg} / \mathrm{kg})$ reverse

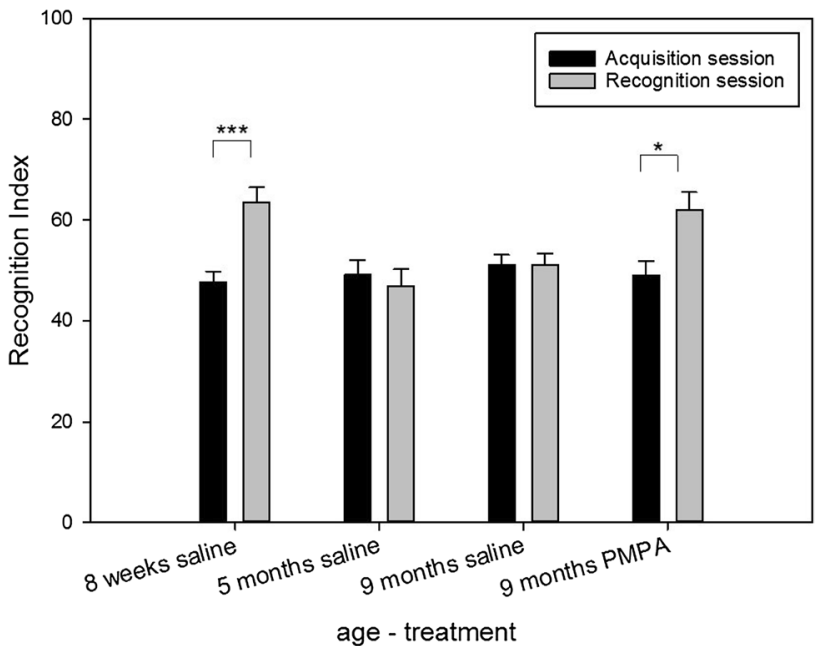

Fig. 2 Short-term novel object recognition memory test in triple transgenic Amice. Eight week old AD mice explored the novel object significantly more than the familiar object while the 9 month old $\mathrm{AD}$ mice failed to discriminate between the novel and familiar object. 2-PMPA $(100 \mathrm{mg} / \mathrm{kg})$ restored the ability of the older mice to discriminate between the novel and familiar object. 8 week, $\mathrm{n}=15 ; 9$ mos/saline, $\mathrm{n}=10 ; 9 \operatorname{mos} / \mathrm{PMPA}, \mathrm{n}=10$

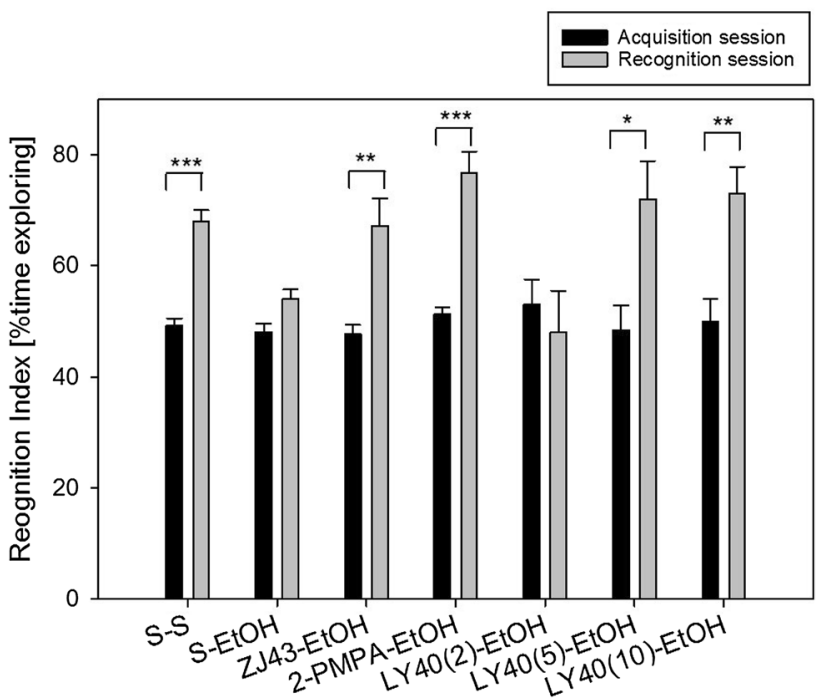

Fig. 3 Ethanol impairment of short-term novel object recognition is reversed by NAAG peptidase inhibitors and the group II mGluR agonist LY354740. Mice treated with two injections of saline before the acquisition phase of the test, explored the novel object significantly more than the familiar object $1.5 \mathrm{~h}$ later (recognition index 70). Ethanol $(2.1 \mathrm{~g} / \mathrm{kg})$ blocked discrimination of the novel object in the retention session. Pretreatment with $\mathrm{ZJ} 43(150 \mathrm{mg} / \mathrm{kg})$ and 2-PMPA (100 mg/kg) reversed the cognitive deficits induced by ethanol. Pretreatment with LY354740(LY40) dose dependently reversed the effects of ethanol. S-S, $n=10 ; \mathrm{S}-\mathrm{EtOH}, \mathrm{n}=11 ; \mathrm{ZJ} 43-\mathrm{EtOH}, \mathrm{n}=6$; 2-PMPA-EtOH, $\mathrm{n}=6$; LY40(2)-EtOH, $\mathrm{n}=12$; LY40(5)-EtOH, $\mathrm{n}=12$; LY40(10)-EtOH, $n=7$ 
the effects of ethanol on novel object recognition $(\mathrm{p}<0.01$, $\mathrm{p}<0.001$ and $\mathrm{p}<0.01$ respectively). A low dose of the type 2/3 metabotropic glutamate receptor antagonist LY341495 $(2 \mathrm{mg} / \mathrm{kg}$ ) failed to block the effects of 2-PMPA on ethanol treatment in this assay. When given alone to control mice prior to acquisition, 2 and $3 \mathrm{mg} / \mathrm{kg}$ of LY341495 reduced memory on the retention trial and could not be used to confirm the role of NAAG at the group II metabotropic glutamate receptors in this study. Mice given $1.7 \mathrm{~g} / \mathrm{kg}$ (i.p.) ethanol did not exhibit a significant loss of short-term memory in this assay (data not shown).

In the absence of confirmation that the mGluR mediated the efficacy of NAAG peptidase inhibition in the ethanol intoxication model, the study was repeated using mGluR2 and mGluR3 ko mice treated with saline or $2.1 \mathrm{mg} / \mathrm{kg}$ (i.p.) ethanol (Fig. 4). Saline treated mice of both strains showed a significant level of recognition of the novel object and this short-term memory was blocked by pretreatment with ethanol. mGluR2 ko mice pretreated with 2-PMPA $(100 \mathrm{mg} / \mathrm{kg})$ prior to ethanol administration demonstrated significant memory $(\mathrm{p}<0.05)$ in the recognition trials while 2-PMPA was without a significant effect in the ethanol treated mGluR3 ko mice.

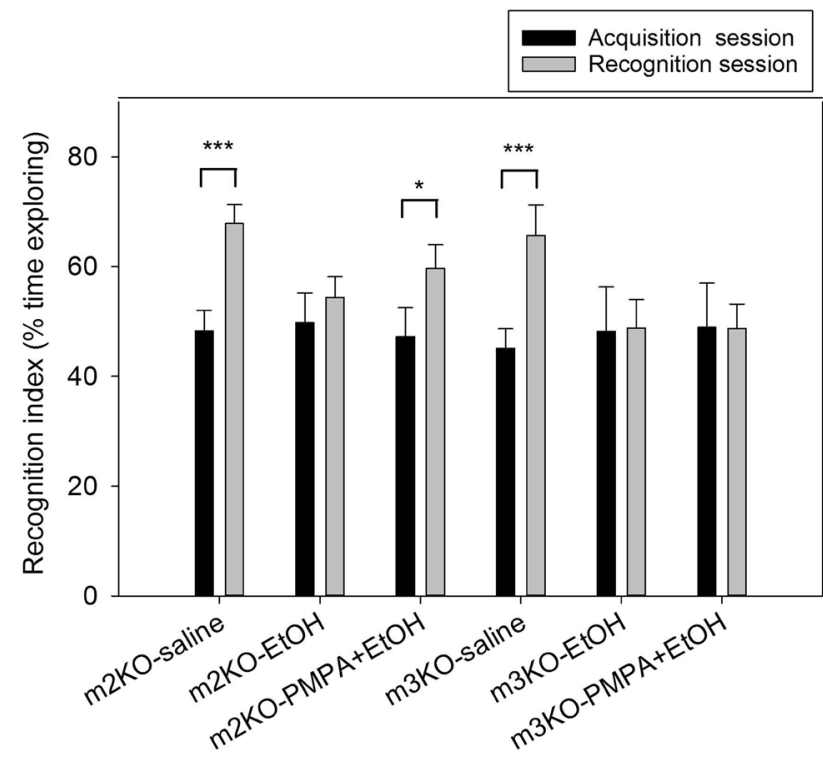

Fig. 4 mGluR3 mediates the procognitive effects of NAAG peptidase inhibition in the ethanol treatment model. mGluR2 (m2KO) and mGluR3 KO (m3KO) mice exhibited short-term (1.5 h) memory in the novel object memory test. Mice of both strains failed to discriminate between the novel and familiar object when treated with $2.1 \mathrm{~g} / \mathrm{kg}$ ethanol prior to the acquisition trial. 2-PMPA $(100 \mathrm{mg} / \mathrm{kg})$ partially reversed the effect of ethanol in mGluR2 but not mGluR3 mice. mGluR2ko-S, $\mathrm{n}=11$; mGluR2ko-EtOH, $\mathrm{n}=12$; mGluR2koPMPA + EtOH, n= 10; mGluR3ko-S, n=9; mGluR3ko-EtOH, n=9; mGluR3ko-PMPA + EtOH, $n=10$
NAAG Peptidase Inhibitors Block Ethanol-Induced Motor Activation

Ethanol (2.1 g/kg, i.p.) induced a prompt increase $(\mathrm{p}<0.001)$ in motor activation in mice placed in an open field chamber to which they previously had been habituated (Fig. 5). There was a main effect of drug (saline, ZJ43 or LY doses, $\left.\mathrm{F}_{(6,80)}=4.679, \mathrm{p}<0.001\right)$ and treatment (saline or ethanol, $\mathrm{F}_{(1,80)}=15.503, \mathrm{p}<0.001$ ). Pretreatment with $\mathrm{ZJ} 43$ (50, 100 and $150 \mathrm{mg} / \mathrm{kg}$, i.p.) dose dependently reduced motor activation during the $10 \mathrm{~min}$ interval immediately following ethanol administration ( $50 \mathrm{mg} / \mathrm{kg}, \mathrm{p}<0.01$ and $150 \mathrm{mg} / \mathrm{kg}, \mathrm{p}<0.001)$. The group II metabotropic glutamate receptor agonist LY354740 $(10 \mathrm{mg} / \mathrm{kg})$ reversed the effects of ethanol $(\mathrm{p}<0.001)$. To confirm the role of NAAG and a type 2 or 3 metabotropic glutamate receptor in mediating the effects of NAAG peptidase inhibition, ZJ43 $(150 \mathrm{mg} / \mathrm{kg})$ was co-administered with the group II antagonist LY341495 (3 mg/ $\mathrm{kg}$ ). The antagonist reversed the effect of $150 \mathrm{mg} / \mathrm{kg}$ ZJ43 ( $\mathrm{p}<0.05)$. The group II mGluR agonist LY354740 $(10 \mathrm{mg} / \mathrm{kg}$, i.p.) also blocked the ethanol effect.

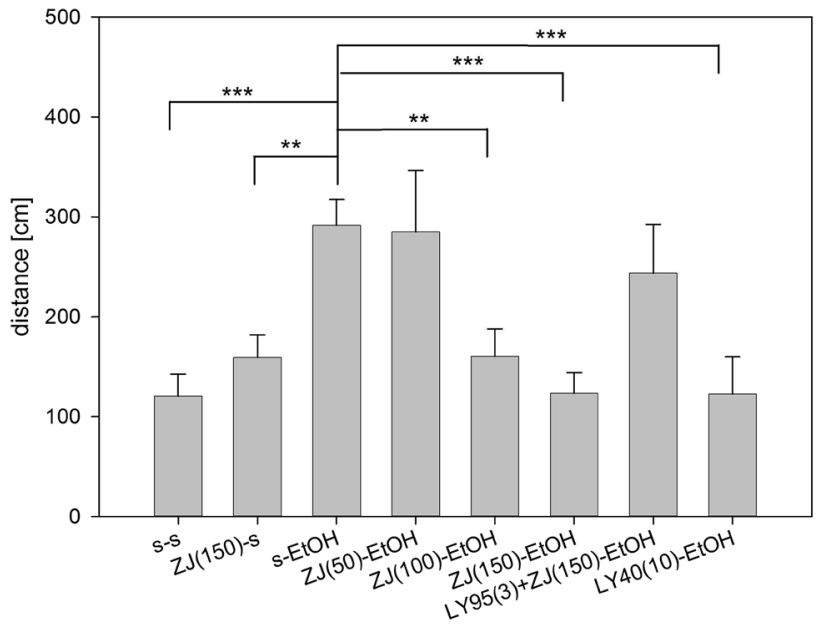

Fig. 5 Ethanol-induced motor activation reversed by ZJ43 and group II agonist LY354740. Ethanol (2.1 g/kg, i.p.) increases motor activation in open field test. Pretreatment with ZJ43 (50, 100 and $150 \mathrm{mg} /$ $\mathrm{kg}$, i.p.) dose dependently reduced motor activation during the $10 \mathrm{~min}$ interval immediately following ethanol administration. The group II metabotropic glutamate receptor agonist LY354740 (10 mg/kg) was similarly effective in moderating the effects of ethanol. The group II metabotropic glutamate receptor antagonist LY341495 reversed the effect of ZJ43 $(150 \mathrm{mg} / \mathrm{kg})$ on ethanol-induced motor activation. S-saline. ZJ $=$ ZJ43, LY95 $=\mathrm{LY} 341495, L Y 40=\mathrm{LY} 354740 . \mathrm{N}: \mathrm{s} / \mathrm{s}$ (11), ZJ150/s, ZJ100/Et-OH, LY95 + ZJ150/Et-OH (9), s/Et-OH (20), ZJ50/Et-OH, ZJ150/Et-OH, LY40/Et-OH (10). *p $<0.05$, **p $<0.01$, $* * * \mathrm{p}<0.001$ 


\section{Rotorod Test of Ethanol-Induced Loss of Motor Coordination or Balance}

In the rotorod test, mice given with ethanol ( $2.5 \mathrm{~g} / \mathrm{kg}$, i.p.). There was a significant effect of drug $\left(\mathrm{F}_{(8,100)}=3.458\right.$, $\mathrm{p}<0.01)$ and treatment $\left(\mathrm{F}_{(1,100)}=22.409, \mathrm{p}<0.001\right)$. Ethanol treatment produced a $55 \%$ reduction in latency to fall from the rotorod relative to saline treated mice $(\mathrm{p}<0.001)$ (Fig. 6). ZJ43 (150 mg/kg, i.p.) blocked this effect of ethanol. 2-PMPA (10, 50 and $100 \mathrm{mg} / \mathrm{kg}$ ) blocked the effect of $2.1 \mathrm{~g} / \mathrm{kg}$ ethanol in a dose-dependent manner $(\mathrm{p}<0.01$ for $100 \mathrm{mg} / \mathrm{kg}$ and $\mathrm{p}<0.05$ for $50 \mathrm{mg} / \mathrm{kg}$ comparing with ethanol group). The effects of ZJ43 and 2-PMPA were reversed by the group II mGluR antagonist LY341495 $(3 \mathrm{mg} / \mathrm{kg}$, $\mathrm{p}<0.05)$ while this antagonist alone had no significant effect on the ethanol-induced loss of motor coordination. The group II mGluR agonist LY354740 (LY40, $10 \mathrm{mg} / \mathrm{kg}$ ) also reduced the effects of $2.1 \mathrm{~g} / \mathrm{kg}$ ethanol on latency to fall (both $\mathrm{p}<0.05$ ).

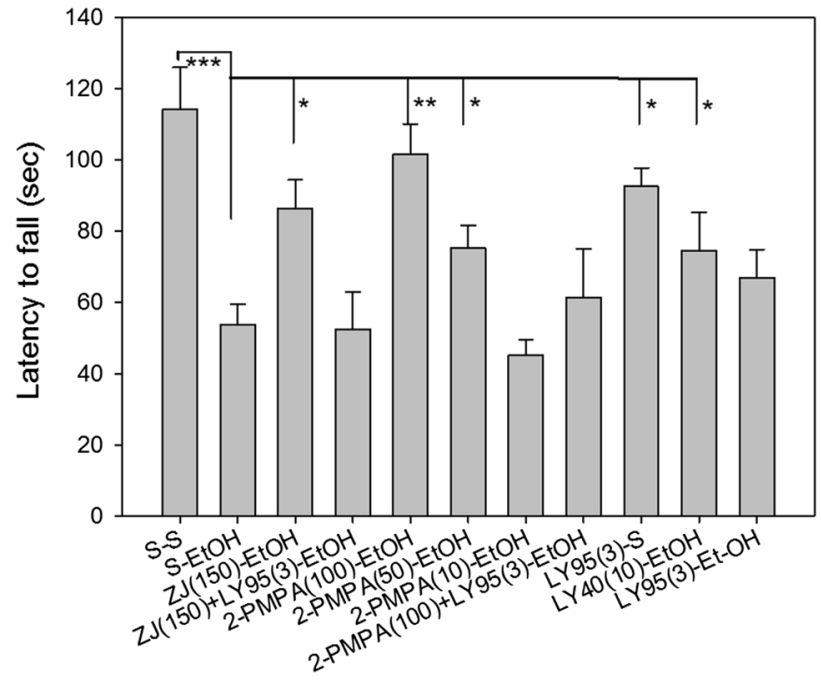

Fig. 6 ZJ43 and 2-PMPA moderate ethanol-induced loss of balance on Rotarod Test. a Ethanol (2.1 g/kg, i.p.) significantly reduced latency to fall relative to saline treated mice $(\mathrm{p}<0.001)$. 2-PMPA reversed the effect in dose dependent manner $(\mathrm{p}<0.01$ for $100 \mathrm{mg} /$ $\mathrm{kg}$ and $\mathrm{p}<0.05$ for $50 \mathrm{mg} / \mathrm{kg}$ comparing with ethanol group). ZJ43 $(150 \mathrm{mg} / \mathrm{kg})$ and LY354740 $(10 \mathrm{mg} / \mathrm{kg})$ also reduced the effects of $2.1 \mathrm{~g} / \mathrm{kg}$ ethanol on latency to fall (both $\mathrm{p}<0.05$ ). The group II antagonist LY341495 $(3 \mathrm{mg} / \mathrm{kg})$ blocked the effect of 2-PMPA (100 mg/ $\mathrm{kg}$ ) and ZJ43 $(150 \mathrm{mg} / \mathrm{kg})$, both at $\mathrm{p}<0.05$ versus 2-PMPA and ZJ43. S-saline, LY95 =LY341495, LY40 =LY354740. All groups are compared individually for statistical significance versus the saline-ethanol group. N: s/s(10), s/EtOH(12), ZJ43-EtOH(12), ZJ43+LY95/ EtOH(17), 2-PMPA100-EtOH(8), 2-PMPA50-EtOH(8), 2-PMPA10EtOH(8), 2-PMPA100 + LY95(3)EtOH(8), LY95/s(10), LY40/ EtOH(8), LY95/EtOH(10)

\section{Discussion}

\section{mGluR3 Mediates Procognitive Efficacy of NAAG Peptidase Inhibition}

The purpose of this study was to further test the procognitive effects of NAAG peptidase inhibition across models of normal memory and in clinically relevant models of cognitive deficits. In parallel, the goal was to test the hypothesis that these procognitive effects are mediated by NAAG activation of the group II metabotropic glutamate receptor, mGluR3. While many strains of mice are reported to demonstrate short-term $(1.5 \mathrm{~h})$ memory in the novel object recognition test, there are no reports of mice exhibiting long-term $(24 \mathrm{~h})$ memory in this test. Similarly, the mGluR2 and mGluR3 ko mice in this study showed significant memory in the short-term test (Fig. 4) and the absence of memory of the familiar object in the long-term memory test (Fig. 1). In previous studies, NAAG peptidase inhibition reversed short-term memory deficits elicited by a low dose of the NMDA antagonist MK801 [11] and had procognitive activity in the $24 \mathrm{~h}$ delay test [7]. Both of these actions were blocked by the group II mGluR antagonist LY341495, consistent with a series of studies that support the conclusion that the peptide mediates group II mGluR activation [20, 42, 43]. The finding that the procognitive effects of 2-PMPA and ZJ43 in the $24 \mathrm{~h}$ delay novel object recognition test were observed in mGluR2 but not mGluR3 ko mice (Fig. 1), supports the conclusion that mGluR3 is the group II receptor mediating these procognitive actions. This conclusion is further strengthened by the efficacy of 2-PMPA in partially reversing ethanol-induced cognitive impairment of short-term memory in mGluR2 but not mGluR3 ko mice (Fig. 4). A similar result in support of a role for mGluR3 in the efficacy of NAAG peptidase inhibition was observed in a mouse model of schizophrenia [10]. Central to the conclusion that these effects of the peptidase inhibitors are mediated by the activation of mGluR3 by elevated levels of synaptically released NAAG, rather than by the drugs directly, are the reports that high levels (100 UM) of ZJ43 and 2-PMPA do not activate group II receptors in vitro $[12,44]$.

These data on the mGluR3 mediated procognitive actions of NAAG peptidase inhibition also are consistent with the broader hypothesis that this receptor plays a more general role in memory formation or retrieval. Supporting this view, mGluR3 ko mice showed deficits in working memory when tested in $\mathrm{T}$ - and $\mathrm{Y}$ mazes and polymorphisms in mGlur3 are associated with cognitive deficits in schizophrenia patients $[45,46]$. 


\section{NAAG as mGluR3 Agonist}

A rigorous study of the effect of purified NAAG on hippocampal slices and cells transfected with mGluR2 or mGluR3 [24] found no evidence of the peptide activating a group II receptor and suggested that some prior reports of NAAG activation of these receptors could have been due to a previous report that commercial NAAG was contaminated with $0.3-0.4 \%$ glutamate [25]. While this glutamate effect cannot be discounted for some studies, it does not seem consistent with other results [42]. For example, NAAG and glutamate dose responses for group II mGluR activation differed by no more than threefold when tested against cerebellar astrocytes, cells that expressed mGluR3 message but little if any mGluR2 [43]. The failure of NAAG to activate group II receptors in transfected cells $[23,24]$ further contrasts the report that NAAG is several orders of magnitude more potent than glutamate in reducing transmitter release from spinal cord synaptosomes [20], an action that was blocked by the group II antagonist LY341495 and the mGluR3 selective antagonist beta-NAAG [47]. Very high levels of NAAG and NAAG peptidase activity are expressed in spinal cord and spinal sensory neurons $[48,49]$ and peptidase inhibition moderated the effect of spinal cord trauma [50].

At the moment, there are not sufficient data to resolve the apparent conflict among the data on the failure of NAAG to activate mGluR3 in transfected cells and the studies presented here and elsewhere $[4,7,10,11,13,20$, 42] in which the effects of NAAG and NAAG peptidase inhibition are blocked by group II mGluR antagonists and are absent in mGluR3 ko mice. One possibility is that the mechanism of expression or dimerization of mGluR3 following its transfection into non-neuronal or -glial cell lines differs from that in vivo, in spinal cord synaptosomes or in cultured astrocytes.

\section{NAAG Peptidase Inhibition in Alzheimer's Disease Model Mice}

The $\mathrm{APP}_{\mathrm{Swe}}, \mathrm{PS} 1_{\mathrm{M} 146 \mathrm{~V}}$, and tau $\mathrm{P}_{\mathrm{P} 01 \mathrm{~L}}$ transgenic mouse line [28] captures both the beta-amyloid and Tau neuropathology found in Alzheimer's disease [51] and thus represents one of the most widely studied animal models of this disorder. Age-dependent behavioral changes have been characterized in this mouse line including deficits in novel object recognition and attention [52-55]. The novel object recognition test also has been used to characterize other transgenic animal models of Alzheimer's disease [35, 56] and recognition memory for novel objects serves as a marker for clinical diagnosis of this disorder [57]. This test is particularly useful in distinguishing cognitive loss in normal aging versus loss in Alzheimer's disease model mice inasmuch as different strains of mice retain short-term memory in the novel object recognition test well beyond 9 months of age even while other cognitive functions are declining [37] In the present study, short-term novel object recognition was observed in the transgenic mice at 2 months but not at 5 and 9 months of age. Consistent with prior reports of procognitive effects of NAAG peptidase inhibition [7, 8, 11], 2-PMPA significantly improved performance on this task in the 9-month old triple mutant Alzheimer's disease mice. While normal 9- month old wild type mice were not tested in this study, a substantial literature demonstrates mice of different strains, including non-transgenic colony mates of triple transgenic Alzheimer's mice do not exhibit a decline in short-term novel object recognition as late as 22 months of age $[36,38,39,58-60]$. Thus, while the behavioral test presented here does not speak to cognitive deficits associated with normal aging in mice, it will be interesting to determine if NAAG peptidase inhibitors are procognitive in other behavioral tests in which normal mice demonstrate aging-related cognitive deficits. In a similar study, we found that ZJ43 also reversed the cognitive deficit of aged triple transgenic mice in the novel object recognition test and the efficacy of ZJ43 was reversed by the group II mGluR antagonist (Olszewski and Neale, work in progress).

\section{Broader Impact of NAAG Peptidase Inhibition in Cognition}

The observations that NAAG peptidase inhibition and deletion of GCPII are procognitive in control conditions, where the mice have not been cognitively challenged via a drug treatment ([7] and Fig. 1), suggest that the procognitive actions of these peptidase inhibitors in animal models of clinical conditions, such as Alzheimer's disease (Fig. 2), schizophrenia [8, 11] and ethanol intoxication (Fig. 3), might not be specifically reversing the neurochemical processes that underlie these clinical models but rather be generally procognitive. However, while the conditions that induce these models are clearly different, they can be linked by the common element of increases in glutamate release and NAAG peptidase inhibitors have been consistently shown to reduce synaptic release of glutamate $[13,14,21$, $22,61-63]$. In any case, the procognitive efficacy of NAAG peptidase inhibition in long-term novel object recognition, demonstrate that NAAG's role on cognition is not limited to deficits induce by excess glutamate release.

In human studies, treatment with growth hormonereleasing hormone increased NAAG levels in the prefrontal cortex and improved performance of subjects exhibiting mild cognitive impairment [64]. Similarly, NAAG levels in the hippocampus positively correlated with cognitive functioning in multiple sclerosis patients [8]. 


\section{Other Group II mGluR Ligands in Cognition Studies}

The mGluR2/3 agonist LY379268 had a procognitive effect in the novel object recognition test [65] while heterotropic group II mGluR agonists and an mGluR2 positive allosteric modulator have procognitive effects in other behavioral tests [66, 67]. Yet in other studies, agonists including the LY354740 impair rather than enhance attention and working memory [68-70]. Interpretation of these reports is complicated by the use of agonists and antagonists that interact with both mGluR2 and mGluR3 in vitro and in vivo [27, 30, 31, 71]. In studies using ko mice, some heterotrophic group II agonists have been shown to work via mGluR2 rather than mGluR3 $[69,72,73]$. This leads to the possibility that the contrasting effects of heterotrophic group II agonists on cognition may reflect differences in the behavioral tests that were used or their differential actions on mGluR2 and mGluR3 receptors. Evidence that the procognitive effects of NAAG peptidase inhibition could be specific to the type of memory being tested comes from the report that $100 \mathrm{mg} / \mathrm{kg}$ of 2-PMPA in mice does not affect long-term memory in the step through passive avoidance test or spatial working memory in the Y maze [74].

\section{NAAG Peptidase Inhibition and Ethanol Induced Cognitive Deficits in Short-Term Novel Object Recognition}

NAAG peptidase inhibition consistently reversed the cognitive impairment induced by ethanol in short-term novel object recognition (Fig. 3 and4). We previously reported that NAAG peptidase inhibition alone had no effects on cognition in this test [11]. The data in Fig. 4 clearly demonstrate that the efficacy of these inhibitors in this short-term memory test require mGluR3. While the effect of 2-PMPA in the mGluR2 ko mice does not reflect a complete reversal of the action of ethanol, the recognition index for this group if mice is significantly different from the acquisition session.

\section{Ethanol, Glutamate and Group II mGluR}

Glutamate appears to have a central role in drug addiction and alcoholism [75]. The efficacy of NAAG peptidase inhibition in reversing the effects of ethanol treatment (Figs. 3, $4,5,6)$ is consistent with the view that group II receptors, particularly mGluR3, are among the more promising targets for the development of drugs to treat alcohol addiction [76-78] Heterotropic group II glutamate receptor agonists reduce drug seeking, conditioned place preference and stress-induced reinstatement in animal models of alcohol addiction [76, 79, 80]. The agonist LY379268 also blocks the effects of alcohol on discriminative stimulus testing
[81], alcohol self-administration and reinstatement [82]. Additionally, epistatic effects of genetic variants of the mGluR3 and COMT genes have been associated with hippocampal volume in alcohol-dependent patients but not in controls [83]. The activity of NAAG peptidase inhibition in the present study might again be related to the efficacy of the peptide in reducing release of glutamate inasmuch as ethanol induces glutamate release in the nucleus accumbens, hippocampus and posterior ventral tegmental area, brain regions known to mediate some of the clinical effects of alcohol consumption [84-86].

The stimulant effects of alcohol in adolescents [40] are modeled in mice by open field motor activation induced immediately after administration [41]. In the present study using mice that previously had been habituated to the open field chamber, ethanol $(2.1 \mathrm{~g} / \mathrm{kg})$ induced an increase in open field activity relative to control mice over the first 10 min minutes after injection (Fig. 5). Pretreatment of mice with NAAG peptidase inhibitors reduced this initial motor activation. Such a result might be taken to indicate that NAAG peptidase inhibitors have a sedative effect as they similarly block motor activation induced by PCP and $d$-amphetamine [9-11, 87]. However, these inhibitors, given alone, do not affect motor activity in control mice habituated or unhabituated to open field conditions [11].

Data from animal models suggest that mGluR3 agonists might be useful in treatment of ethanol addiction [76-78]. The data presented here demonstrate that drugs that elevate NAAG levels also moderate motor activation, cognitive and balance effects of ethanol intoxication and support the conclusion that mGluR3 mediates these effects. The breadth of actions of NAAG peptidase inhibitors in these studies suggests that they may be affecting a central mechanism underlying ethanol-induced intoxication.

\section{Conclusion}

NAAG peptidase inhibition improves cognition in the novel object recognition tests and reduces the cognitive and motor deficits induced by ethanol via a cellular mechanism that involves activation of mGluR3. The GCPII inhibitor 2-PMPA also reverses the cognitive deficit observed in an animal model of Alzheimer's disease. These and other data support the conclusion that GCPII is a significant target for the development of procognitive drugs.

Acknowledgements This research was supported by NIH (R01 MH 79983), Georgetown University Biology Department, and an endowment and generous gifts from Nancy and Daniel Paduano. Eli Lilly Research provided group II metabotropic glutamate receptor knockout mice. While the patent for ZJ43 is held by Georgetown University, the authors have no proprietary interest in this compound. Authors have 
no commercial associations that might pose a conflict of interest in connection with this submitted article.

Open Access This article is distributed under the terms of the Creative Commons Attribution 4.0 International License (http:// creativecommons.org/licenses/by/4.0/), which permits unrestricted use, distribution, and reproduction in any medium, provided you give appropriate credit to the original author(s) and the source, provide a link to the Creative Commons license, and indicate if changes were made.

\section{References}

1. Neale JH, Olszewski RT, Gehl LM, Wroblewska B, Bzdega T (2005) The neurotransmitter $N$-acetylaspartylglutamate in models of pain, ALS, diabetic neuropathy, CNS injury and schizophrenia. Trends Pharmacol Sci 26:477-484

2. Zhou J, Neale JH, Pomper MG, Kozikowski AP (2005) NAAG peptidase inhibitors and their potential for diagnosis and therapy. Nat Rev Drug Discov 4:1015-1026

3. Tsukamoto T, Wozniak KM, Slusher BS (2007) Progress in the discovery and development of glutamate carboxypeptidase II inhibitors. Drug Discov Today 12:767-776

4. Neale JH, Olszewski RT, Zuo D, Janczura KJ, Profaci CP, Lavin KM, Madore JC, Bzdega T (2011) Advances in understanding the peptide neurotransmitter NAAG and appearance of a new member of the NAAG neuropeptide family. J Neurochem 118:490-498

5. Thomas AG, Wozniak KM, Tsukamoto T, Calvin D, Wu Y, Rojas C, Vornov J, Slusher BS (2006) Glutamate carboxypeptidase II (NAALADase) inhibition as a novel therapeutic strategy. Adv Exp Med Biol 576:327-337

6. Wozniak KM, Rojas C, Wu Y, Slusher BS (2012) The role of glutamate signaling in pain processes and its regulation by GCP II inhibition. Curr Med Chem 19:1323-1334

7. Janczura KJ, Olszewski RT, Bzdega T, Bacich DJ, Heston WD, Neale JH (2013) NAAG peptidase inhibitors and deletion of NAAG peptidase gene enhance memory in novel object recognition test. Eur J Pharmacol 701:27-32

8. Rahn KA, Watkins CC, Alt J, Rais R, Stathis M, Grishkan I, Crainiceau CM, Pomper MG, Rojas C, Pletnikov MV, Calabresi PA, Brandt J, Barker PB, Slusher BS, Kaplin AI (2012) Inhibition of glutamate carboxypeptidase II (GCPII) activity as a treatment for cognitive impairment in multiple sclerosis. Proc Natl Acad Sci USA 109:20101-20106

9. Olszewski RT, Bukhari N, Zho J, Kozikowski AP, Wroblewski JT, Shamimi-Noori S, Wroblewska B, Bzdega T, Vicini S, Barton FB, Neale JH (2004) NAAG peptidase inhibition reduces locomotor activity and some stereotypes in the PCP model of schizophrenia via group II mGluR. J Neurochem 89:876-885

10. Olszewski RT, Bzdega T, Neale JH (2012) mGluR3 and not mGluR2 Receptors Mediate the Efficacy of NAAG Peptidase Inhibitor in PCP Model of Schizophrenia. Schizophrenia Res 136:160-161

11. Olszewski RT, Janczura KJ, Ball SR, Madore JC, Lavin KM, Lee JC-M, Lee MJ, Der EK, Hark TJ, Farago PR, Profaci CP, Bzdega T, Neale JH (2012) NAAG peptidase inhibitors block cognitive deficit induced by MK-801 and motor activation induced by d-amphetamine and PCP in animal models of Schizophrenia. Transl Psychiatry 2:e145-e155

12. Yamamoto T, Hirasawa S, Wroblewska B, Grajkowska E, Zhou J, Kozikowski A, Wroblewski J, Neale JH (2004) Antinociceptive effects of $N$-acetylaspartylglutamate (NAAG) peptidase inhibitors ZJ-11, ZJ-17 and ZJ-43 in the rat formalin test and in the rat neuropathic pain model. Eur J Neurosci 20:483-494

13. Yamada T, Zuo D, Yamamoto T, Olszewski RT, Bzdega T, Moffett JR, Neale JH (2012) NAAG peptidase inhibition in the periaqueductal gray and rostral ventromedial medulla reduces flinching in the formalin model of inflammation. Mol Pain 8:67-80

14. Nonaka T, Yamada T, Ishimura T, Zuo D, Neale J H, Yamamoto $\mathrm{T}$ (2016) A role for the Locus Coeruleus in the analgesic efficacy of $\mathrm{N}$-acetylaspartylglutamate (NAAG) peptidase (GCPII) inhibitors ZJ43 and 2-PMPA. Mol Pain (under review)

15. Zhong C, Zhao X, Sarva J, Kozikowski A, Neale JH, Lyeth BG. J (2005) NAAG peptidase inhibitor reduces acute neuronal degeneration and astrocyte damage following lateral fluid percussion TBI in rats. Neurotrauma 22:266-276

16. Bacich DJ, Wozniak KM, Lu XC, O'Keefe DS, Callizot N, Heston WD, Slusher BS (2005) Mice lacking glutamate carboxypeptidase II are protected from peripheral neuropathy and ischemic brain injury. J Neurochem 95:314-323

17. Gao Y, Xu S, Cui Z, Zhang M, Lin Y, Cai L, Wang Z, Luo X, Zheng Y, Wang Y, Luo Q, Jiang J, Neale JH, Zhong C. J (2015) Mice lacking glutamate carboxypeptidase II develop normally, but are less susceptible to traumatic brain injury. $\mathrm{J}$ Neurochem 134:340-353

18. Cao Y, Gao Y, Xu S, Bao J, Lin Y, Luo X, Wang Y, Luo Q, Jiang J, Neale JH, Zhong C (2016) Glutamate carboxypeptidase II gene knockout attenuates oxidative stress and cortical apoptosis after traumatic brain injury. BMC Neurosci 17:15. doi:10.1186/ s12868-016-0251-1

19. Zhao J, Ramadan E, Cappiello M, Wroblewska B, Bzdega T, Neale JH (2001) NAAG inhibits KCl-induced [(3)H]-GABA release via mGluR3, cAMP, PKA and L-type calcium conductance. Eur J Neurosci 2:340-346

20. Romei C, Raiteri M, Raiteri L (2013) Glycine release is regulated by metabotropic glutamate receptors sensitive to mGluR2/3 ligands and activated by $N$-acetylaspartylglutamate (NAAG). Neuropharmacology 66:311-316

21. Zhong C, Zhao X, Van KC, Bzdega T, Smyth A, Zhou J, Kozikowski AP, Jiang J, O'Connor WT, Berman RF, Neale JH, Lyeth BG (2006) NAAG peptidase inhibitor increases dialysate NAAG and reduces glutamate, aspartate and GABA levels in the dorsal hippocampus following fluid percussion injury in the rat. J Neurochem 97:1015-1025

22. Zuo D, Bzdega T, Olszewski RT, Moffett JR, Neale JH (2012) Effects of NAAG peptidase inhibition on release of glutamate and dopamine in the prefrontal cortex and nucleus accumbens in the phencyclidine model of schizophrenia. J Biol Chem 287:21773-21783

23. Chopra M, Yao Y, Blake, T J, Hampson DR, Johnson EC (2009) The neuroactive peptide $N$-acetylaspartylglutamate is not an agonist at the metabotropic glutamate receptor subtype 3 of metabotropic glutamate receptor. J Pharmacol Exp Ther 330:212-219

24. Fricker AC, Mok MH. de la Flor R, Shah AJ, Woolley M, Dawson LA, Kew JN (2009) Effects of $N$-acetylaspartylglutamate (NAAG) at group II mGluRs and NMDAR. Neuropharmacology 56:1060-1067

25. Losi G, Vicini S, Neale J (2004) NAAG fails to antagonize synaptic and extrasynaptic NMDA receptors in cerebellar granule neurons. Neuropharmacology 4:490-496

26. Khacho P, Wang B, Ahlskog N et al (2015) Differential effects of $\mathrm{N}$-acetyl-aspartyl-glutamate on synaptic and extrasynaptic NMDA receptors are subunit- and $\mathrm{pH}$-dependent in the CA1 region of the mouse hippocampus. Neurobiol Dis 282:580-592

27. Linden AM, Johnson BG, Trokovic N, Korpi ER, Schoepp DD (2009) Use of MGLUR2 and MGLUR3 knockout mice to explore in vivo receptor specificity of the MGLUR2/3 selective antagonist LY341495. Neuropharmacology 57:172-182 
28. Oddo S, Caccamo A, Shepherd JD, Murphy MP, Golde TE, Kayed R, Metherate R, Mattson MP, Akbari Y, LaFerla FM (2003) Triple-transgenic model of Alzheimer's disease with plaques and tangles: intracellular Abeta and synaptic dysfunction. Neuron 39:409-421

29. Jackson PF, Slusher S (2001) Design of NAALADase inhibitors: a novel neuroprotective strategy. Curr Med Chem 8:949-957

30. Kingston AE, Ornstein PL, Wright RA, Johnson BG, Mayne NG, Burnett JP, Belagaje R, Wu S, Schoepp DD (1998) LY341495 is a nanomolar potent and selective antagonist of group II metabotropic glutamate receptors. Neuropharmacology 37:1-12

31. Monn JA, Valli MJ, Massey SM, Korpi ER, Schoepp DD (1999) Synthesis, pharmacological characterization, and molecular modeling of heterobicyclic amino acids related to (+)-2-aminobicyclo[3.1.0] hexane-2,6-dicarboxylic acid (LY354740): identification of two new potent, selective, and systemically active agonists for group II metabotropic glutamate receptors. J Med Chem 42:1027-1040

32. Antunes M, Biala G (2012) The novel object recognition memory: neurobiology, test procedure, and its modifications. Cogn Process 13:93-110

33. Akkerman S, Prickaerts J, Steinbusch HW, Blokland A (2012) Object recognition testing: statistical considerations. Behav Brain Res 232:317-322

34. Lyon L, Saksida LM, Bussey TJ (2012) Spontaneous object recognition and its relevance to schizophrenia: a review of findings from pharmacological, genetic, lesion and developmental rodent models. Psychopharmacology (Berl) 220:647-672

35. Zhang R, Xue G, Wang S, Zhang L, Shi C, Xie X (2012) Novel object recognition as a facile behavior test for evaluating drug effects in A $\beta P P / P S 1$ Alzheimer's Disease mouse model. J Alzheimers Dis 31:801-812

36. Kesby JP, Kim JJ, Scadeng M, Woods G, Kado DM, Olefsky JM, Jeste DV, Achim CL, Semenova S (2015) Spatial cognition in adult and aged mice exposed to high-fat diet. PLoS ONE 10(10): 0140034

37. Fahlström A, Yu Q, Ulfhake B (2011) Behavioral changes in aging female C57BL/6 mice. Neurobiol Aging 32:1868-1880

38. Filali M, Lalonde R, Theriault P, Julien C, Calon F, Planel E (2012) Cognitive and non-cognitive behaviors in the triple transgenic mouse model of Alzheimer's disease expressing mutated APP, PS1, and Mapt (3xTg-AD). Behav Brain Res 234:334-342

39. Ryan D, Koss D, Porcu E, Woodcock H, Robinson L, Platt B, Riedel GA (2013) Spatial learning impairments in PLB1Triple knock-in Alzheimer mice are task-specific and age-dependent. Cell Mol Life Sci 70:2603-2619

40. Acevedo MB, Molina JC, Nizhnikov ME, Spear NE, Pautassi RM (2010) High ethanol dose during early adolescence induces locomotor activation and increases subsequent ethanol intake during late adolescence. Dev Psychobiol 52:424-440

41. Baliño P, Pastor R, Aragon CM (2010) Participation of L-type calcium channels in ethanol-induced behavioral stimulation and motor incoordination: effects of diltiazem and verapamil. Behav Brain Res 209:196-204

42. Neale JH (2011) N-Acetylaspartylglutamate (NAAG) IS an agonist at mGluR3 in vivo and in vitro. J Neurochem 119:891-895

43. Wroblewska B, Santi MR, Neale JH (1998) $N$-acetylaspartylglutamate activates cyclic AMP-coupled metabotropic glutamate receptors in cerebellar astrocytes. Glia 24:172-179

44. Yamamoto T, Saito O, Aoe T, Bartolozzi A, Sarva J, Zhou J, Kozikowski A, Wroblewska B, Bzdega T, Neale JH (2007) Local administration of $\mathrm{N}$-acetylaspartylglutamate (NAAG) peptidase inhibitors is analgesic in peripheral pain in rats. Eur $\mathbf{J}$ Neurosci 25:147-158

45. Lainiola M, Procaccini C, Linden AM (2014) mGluR3 knockout mice show a working memory defect and an enhanced response to MK-801 in the T- and Y-maze cognitive tests. Behav Brain Res 266:94-103

46. Jablensky A, Morar B, Wiltshire S, Carter K, Dragovic M, Badcock JC, Chandler D, Peters K, Kalaydjieva L (2011) Polymorphisms associated with normal memory variation also affect memory impairment in schizophrenia. Genes Brain Behav 10:410-417

47. Lea PM 4th, Wroblewska B, Sarvey JM, Neale JH (2001) betaNAAG rescues LTP from blockade by NAAG in rat dentate gyrus via the type 3 metabotropic glutamate receptor. J Neurophysiol 8:1097-1106

48. Cangro CB, Namboodiri MA, Sklar LA, Corigliano-Murphy A, Neale JH (1987) Immunohistochemistry and biosynthesis of $\mathrm{N}$-acetylaspartylglutamate in spinal sensory ganglia. J Neurochem 49:1579-1588

49. Fuhrman S, Palkovits M, Cassidy M, Neale JH (1994) The regional distribution of $N$-acetylaspartylglutamate (NAAG) and peptidase activity against NAAG in the rat nervous system. J Neurochem 62:275-281

50. Long JB, Yourick DL, Slusher BS, Robinson MB, Meyerhoff JL (2005) Inhibition of glutamate carboxypeptidase II (NAALADase) protects against dynorphin A-induced ischemic spinal cord injury in rats. Eur J Pharmacol 508:115-122

51. Mastrangelo MA, Bowers WJ (2008) Detailed immunohistochemical characterization of temporal and spatial progression of Alzheimer's disease-related pathologies in male triple-transgenic mice. BMC Neurosci 9:81. doi:10.1186/1471-2202-9-81

52. Pietropaolo S, Feldon J, Yee BK (2008) Age-dependent phenotypic characteristics of a triple transgenic mouse model of Alzheimer disease. Behav Neurosci 122:733-747

53. Romberg C, Mattson MP, Mughal MR, Bussey TJ, Saksida LM (2011) Impaired attention in the 3xTgAD mouse model of Alzheimer's disease: rescue by donepezil (Aricept). J Neurosci 31:3500-3507

54. Davis KE, Eacott MJ, Easton A, Gigg J (2013) Episodic-like memory is sensitive to both Alzheimer's-like pathological accumulation and normal ageing processes in mice. Behav Brain Res 254:73-82

55. Webster SJ, Bachstetter AD, Nelson PT, Schmitt FA, Van Eldik LJ (2014) Using mice to model Alzheimer's dementia: an overview of the clinical disease and the preclinical behavioral changes in 10 mouse models. Front Genet 5:88. doi:10.3389/ fgene.2014.00088

56. Greco SJ, Bryan KJ, Sarkar S, Zhu X, Smith MA, Ashford JW, Johnston JM, Tezapsidis N, Casadesus G (2010) Leptin reduces pathology and improves memory in a transgenic mouse model of Alzheimer's disease. J Alzheimers Dis 19:1155-1167

57. Lee AC, Rahman S, Hodges JR, Sahakian BJ, Graham KS (2003) Associative and recognition memory for novel objects in dementia: implications for diagnosis. Eur J Neurosci 18:1660-1670

58. Ohta H, Arai S, Akita K, Ohta T, Fukuda S (2012) Effects of NK-4 in a transgenic mouse model of Alzheimer's disease. PLoS One 7:e30007. doi:10.1371/journal.pone.0030007

59. Mouri A, Noda Y, Hara H, Mizoguchi H, Tabira T, Nabeshima $\mathrm{T}$ (2007) Oral vaccination with a viral vector containing Abeta cDNA attenuates age-related Abeta accumulation and memory deficits without causing inflammation in a mouse Alzheimer model. FASEB J 21:2135-2148

60. Webster SJ, Bachstetter AD, Van Eldik LJ (2013) Comprehensive behavioral characterization of an APP/PS-1 double knock-in mouse model of Alzheimer's disease. Alzheimers Res Ther 5:28. doi:10.1186/alzrt182

61. Adedoyin MO, Vicini S, Neale JH (2010) Endogenous $N$-acetylaspartylglutamate (NAAG) inhibits synaptic plasticity/transmission in the amygdala in a mouse inflammatory pain model. Mol Pain 6:60. doi:10.1186/1744-8069-6-60 
62. Slusher BS, Vornov JJ, Thomas AG, Hurn PD, Harukuni I, Bhardwaj A, Traystman RJ, Robinson MB, Britton P, Lu XC, Tortella FC, Wozniak KM, Yudkoff M, Potter BM, Jackson PF (1999) Selective inhibition of NAALADase, which converts NAAG to glutamate, reduces ischemic brain injury. Nat Med 5:1396-1402

63. Sanabria ER, Wozniak KM, Slusher BS, Keller A. J (2004) GCP II (NAALADase) inhibition suppresses mossy fiber-CA3 synaptic neurotransmission by a presynaptic mechanism. J Neurophysiol 91:182-93

64. Friedman SD, Baker LD, Borson S, Jensen JE, Barsness SM, Craft S, Merriam GR, Otto RK, Novotny EJ, Vitiello MV (2013) Growth hormone-releasing hormone effects on brain $\gamma$-aminobutyric acid levels in mild cognitive impairment and healthy aging. JAMA Neurol 70:883-890

65. Jones CA, Brown AM, Auer DP, Fone KC (2010) The mGluR2/3 agonist LY379268 reverses post-weaning social isolationinduced recognition memory deficits in the rat. Psychopharmacology (Berl) 214:269-283

66. Boyle J, Trick L, Soo-ampon S., Lilley S, Levine L, Hindmarch I (2003) Evaluation of cognitive and psychomotor profile of a novel anxiolytic, LY544344, compared to lorazepam in normal volunteers. Eur Neurophychopharmacol 13:S355

67. Nikiforuk A, Popik P, Drescher KU, van Gaalen M, Relo AL, Mezler M, Marek G, Schoemaker H, Gross G, Bespalov A (2010) Effects of a positive allosteric modulator of group II metabotropic glutamate receptors, LY487379, on cognitive flexibility and impulsive-like responding in rats. J Pharmacol Exp Ther 335:665-673

68. Aultman JM, Moghaddam B (2001) Distinct contributions of glutamate and dopamine receptors to temporal aspects of rodent working memory using a clinically relevant task. Psychopharmacology (Berl) 153:353-364

69. Higgins GA, Ballard TM, Kew JN, Richards JG, Kemp JA, Adam G, Woltering T, Nakanishi S, Mutel V (2004) Pharmacological manipulation of mGlu2 receptors influences cognitive performance in the rodent. Neuropharmacology 46:907-917

70. Spinelli S, Ballard T, Gatti-McArthur S, Richards GJ, Kapps M, Woltering T, Wichmann J, Stadler H, Feldon J, Pryce CR (2005) Effects of the mGluR2/3 agonist LY354740 on computerized tasks of attention and working memory in marmoset monkeys. Psychopharmacology (Berl) 179:292-302

71. Rorick-Kehn LM, Johnson BG, Burkey JL, Wright RA, Calligaro DO, Marek GJ, Nisenbaum ES, Catlow JT, Kingston AE, Giera DD, Herin MF, Monn JA, McKinzie DL, Schoepp DD (2007) Pharmacological and pharmacokinetic properties of a structurally novel, potent, and selective metabotropic glutamate $2 / 3$ receptor agonist: in vitro characterization of agonist (-)-(1R,4 S,5 S,6S)-4-amino-2-sulfonylbicyclo[3.1.0]-hexane-4,6-dicarboxylic acid (LY404039). J Pharmacol Exp Ther 321:308-317

72. Fell MJ, Svensson KA, Johnson BG, Schoepp DD (2008) Evidence for the role of metabotropic glutamate (mGlu)2 not mGlu3 receptors in the preclinical antipsychotic pharmacology of the mGlu2/3 receptor agonist (-)-(1R,4 S,5 S,6S)-4-amino-2-sulfonylbicyclo[3.1.0]hexane-4,6-dicarboxylic acid (LY404039). J Pharmacol Exp Ther 326:209-217

73. Woolley ML, Pemberton DJ, Bate S, Corti C, Jones DN (2008) The mGlu2 but not the mGlu3 receptor mediates the actions of the mGluR2/3 agonist, LY379268, in mouse models predictive of antipsychotic activity. Psychopharmacology (Berl) 196:431-440

74. Lukawski K, Kamiński RM, Czuczwar SJ (2008) Effects of selective inhibition of $\mathrm{N}$-acetylated-alpha-linked-acidic dipeptidase (NAALADase) on mice in learning and memory tasks. Eur J Pharmacol 579:202-207

75. Gass JT, Olive MF (2008) Glutamatergic substrates of drug addiction and alcoholism. Biochem Pharmacol 75:218-265

76. Olive MF (2009) Metabotropic glutamate receptor ligands as potential therapeutics for addiction. Curr Drug Abuse Rev 2:83-98

77. Spanagel R (2009) Alcoholism: a systems approach from molecular physiology to addictive behavior. Physiol Rev 89:649-705

78. Spanagel R, Kiefer F (2008) Drugs for relapse prevention of alcoholism: ten years of progress. Trends Pharmacol Sci 29:109-115

79. Sidhpura N, Weiss F, Martin-Fardon R (2010) Effects of the mGlu2/3 agonist LY379268 and the mGlu5 antagonist MTEP on ethanol seeking and reinforcement are differentially altered in rats with a history of ethanol dependence. Biol Psychiatry 67:804-811

80. Zhao Y, Dayas CV, Aujla H, Baptista MA, Martin-Fardon R, Weiss F (2006) Activation of group II metabotropic glutamate receptors attenuates both stress and cue-induced ethanol-seeking and modulates c-fos expression in the hippocampus and amygdala. J Neurosci 26:9967-9974

81. Cannady R, Grondin JJ, Fisher KR, Hodge CW, Besheer J (2011) Activation of group II metabotropic glutamate receptors inhibits the discriminative stimulus effects of alcohol via selective activity within the amygdala. Neuropsychopharmacology 36:2328-2338

82. Backstrom P, Hyytia P (2005) Suppression of alcohol selfadministration and cue-induced reinstatement of alcohol seeking by the mGlu2/3 receptor agonist LY379268 and the mGlu8 receptor agonist (S)-3,4-DCPG. Eur J Pharmacol 528:110-118

83. Puls I, Mohr J, Wrase J, Priller J, Behr J, Kitzrow W, Makris N, Breiter HC, Obermayer K, Heinz A (2008) Synergistic effects of the dopaminergic and glutamatergic system on hippocampal volume in alcohol-dependent patients. Biol Psychol 79:126-136

84. Lallemand F, Ward RJ, De Witte P, Verbanck P (2011) Binge drinking $+/-$ chronic nicotine administration alters extracellular glutamate and arginine levels in the nucleus accumbens of adult male and female Wistar rats. Alcohol 46:373-382

85. Chefer V, Meis J, Wang G, Kuzmin A, Bakalkin G, Shippenberg $\mathrm{T}$ (2011) Repeated exposure to moderate doses of ethanol augments hippocampal glutamate neurotransmission by increasing release. Addict Biol 16:229-237

86. Ding ZM, Engleman EA, Rodd ZA, McBride WJ (2012) Ethanol increases glutamate neurotransmission in the posterior ventral tegmental area of female wistar rats. Alcohol Clin Exp Res 36:633-640

87. Olszewski RT, Wegorzewska MM, Monteiro AC, Krolikowski KA, Zhou J, Kozikowski AP, Long K, Mastropaolo J, Deutsch SI, Neale JH (2008) Phencyclidine and dizocilpine induced behaviors reduced by $N$-acetylaspartylglutamate peptidase inhibition via metabotropic glutamate receptors. Biol Psychiatry 63:86-91 